\title{
The Judiciary and (Labour) Law in the Development Discourse in India
}

\author{
By Supriya Routh, Kolkata*
}

\section{A. Introduction}

Development agenda is successfully invoked for interventionist measures by the developed countries, international organizations and private entities in a target so called non-developed country. The inviolability of the idea of this country based development discourse often is perceived to be dependent on the legal regime (that includes both the legal framework as well as the substantive laws), expressed through the 'rule of law' rhetoric of the targeted country. According to this interventionist's understanding legal regimes must have specific characteristics to fit in the development discourse (or rather, shape the development discourse). Regimes that lack such specific characteristics are diplomatically and militarily forced to institute such characteristics in their legal regimes. The law and development discourse, thus, encloses itself in a top-down monolithic construct of interdependence shaped from a privileged vantage point. By doing this it ends up diluting the emancipatory potential of the discourse which purportedly is the raison d'etre of the discourse.

I will argue in this essay that the legal regime clinically devised in the development discourse is potentially antithetical to the 'emancipatory trajectory' of the domestic legal regime already in existence in the target country. By 'emancipatory trajectory' I mean the domestic institutional guarantees and existing framework (incorporated in the Constitution of a country, especially in India scenario) for the improvement and continuous development of the workers and other marginalized section of the population. 'Emancipation' is a dynamic expression that signifies 'freedom from legal, social, or political restraint'. 'I have used 'emancipation' to mean improvement of the plight of the workers, not only in absolute terms of pulling them up from poverty, but by continuously allowing them the opportunity to improve their lives the way they desire. My argument through the rest of the essay is premised on my understanding that 'emancipation' in a country context has a definite meaning, peculiar to the historical, social, economic and politico-cultural characteristics ${ }^{2}$ of the country. In the following sections of the essay I tie my idea of 'emancipation' to one of the developmental theories to couch the issue in 'law and development' terms. To prove my

* Supriya Routh is an Assistant Professor at the West Bengal National University of Juridical Sciences (WB NUJS), Kolkata, India. E-mail: supriyonujs@gmail.com. The author thanks Prof. Hester Lessard, Professor, University of Victoria, Canada and Prof. Sourav Bhattacharya, Assistant Professor, WB NUJS, India, for their comments on earlier versions of the draft. The usual caveat applies. E-mail: supriyonujs@gmail.com Black's Law Dictionary, Eighth Edition, 2004.

2 A. Payne, The Global Politics of Unequal Development, New York 2005, p. 233-240. 
thesis I will look into the development rhetoric and the legal regime in India. I will chart the course of development potential of the workers in the country and look into the role of labour law in such development discourse. I will show that the law and development discourse in its present formulation is actually an obstacle in the actual potential for development (by which I mean 'emancipation') of the workers in the country. To pursue the abovementioned course I first need to address the meaning of the oft iterated country-specific development discourse as is dominantly understood.

\section{B. Defining Development}

Shmuel Eisenstadt asserted that the quest of modern nations is development from premodern societies to modern societies. ${ }^{3}$ This development towards modernization means 'the process of change towards those types of social, economic and political systems that have developed in Western Europe and North America from the seventeenth century to the nineteenth'. ${ }^{4}$ The modernization indicators are individual freedom, institutional structures, technocratic improvement, urbanization, shift from traditional mode of production to newer modes, growth of per-capita income, growth of market for goods, labour, money and plethora of other micro and macro characteristics. ${ }^{5}$ Thus, the modern nation-state development is characterized as essentially the process of Westernization of the 'non-developed' world. Such an understanding also underlies the work of the global rebuilding and financing organizations, highly influenced by the neo-liberal doctrine. ${ }^{6}$ The conceptual framework of the development dogma rests on the three principal interrelated understanding of the idea 'development': the sustainable livelihoods concept, the human capability concept and the empowerment concept. ${ }^{7}$ The sustainable livelihoods concept approaches development from individual capacity and assets building perspective. Sustainable development was famously defined by Brundtland as: 'development that meets the needs of the present without compromising the ability of future generations to meet their own needs. ${ }^{, 8}$ The concept was not so much concerned with ecological limits as it was with socio-economic

Shmuel N. Eisenstadt, The Basic Characteristics of Modernization, in: Shmuel N. Eisenstadt (ed.), Modernization, Protest and Change, Eaglewood Cliffs 1966, p. 1. available at http://www.europa. clio-online.de/portals/_Europa/ documents/fska/Q_2005_FS2-08.pdf, (accessed 4 August, 2010).

4 Ibid., p. 1 .

5 Ibid., pp. 1-3.

6 See D. Craig and D. Porter, Development Beyong Neoliberalism? Governance, poverty reduction and political economy, New York 2006, p. 10-15, 54-75.

A. Trebilcock, Using Development Approaches to Address the Challenge of the Informal Economy for Labour Law, in: Guy Davidov and Brian Langille (eds.), Boundaries and Frontiers of Labour Law, Oxford and Portland 2006, pp. 76-84.

8 Gro H. Bruntland et al, Our Common Future - World Commission on Environment and Development, Oxford 1987, p. 43. 
restraints to development. ${ }^{9}$ The concept views development as a continuous sustainable process rather than growth in absolute terms; it considers the domestic socio-ecological system as inherently connected to the global system; it recognizes the complementarity of natural and other capital; it propagates intergenerational equity; it proposes decentralization of decision-making; and adoption of precautionary principles in decision making involving ecology. ${ }^{10}$ The concept explains that individual's skill, education, awareness, network, along with appropriate policy determination by the State would enable sustainable development at the micro level. ${ }^{11}$ Sustainability of development at the micro level is in essence the capacity of individuals to cope with uncertainties and shocks of livelihood. ${ }^{12}$

Second, the human capability concept ${ }^{13}$ rests on building human capacity (capability) (or human resource) to enable participation in the larger political and economic process. ${ }^{14}$ Such individual participation is interwoven with the human rights agenda. ${ }^{15}$ The purpose of the approach is realization of the civil, political, economic, social and cultural freedom at the individual level to ensure effective participation in the overall socio-economic-political process. To Sen, proponent of the idea, the principle of freedom is the primary end as well as the principal means of the development process. ${ }^{16}$ Sen's idea of development advocates the rejection of the narrower view of development based only on 'economic growth' terms in favour of a broader concept of development as freedom and autonomy. ${ }^{17}$ According to

Philippe J. Crabbe, Sustainable Development: Concepts, Measures, Market and Policy Failures at the Open Economy, Industry and Firm Levels, 1997, p. 7-15, available at http://socserv2.socsci. mcmaster.ca/ econ/ faculty/ mullera/cansee/papers/crabbe/susdev.htm (site visited 6 December 2010).

Ibid., pp. 15-23.

Trebilcock, note 7, pp. 76-84.

The factors in sustainable development are: 'Raising human capital through health and education; Enhancing social capital through raising people's awareness of their rights and obligations; Expansion of options and opportunities through responding to evolving global markets; Improvement in the policy and institutional context of livelihoods, due to the whole array of factors tackled by efforts to improve governance.' See F. Ellis and J. Seeley, Background Briefing: Globalization and Sustainable Livelihoods: An Initial Note, 2001, p. 2, as cited in Trebilcock, note 7, p. 77.

Amartya Sen, Development as Freedom, New York 1999. Sen's conception of development as expansion of human capabilities is compatible with the definition of sustainable development offered in the 1987 Brundtland Report, which is 'development that meets the needs of the present without comprising the ability of future generations to meet their own needs'; see Judy Fudge, 'Gender, Equality and Capabilities: Care Work and Sustainable Development' (2010), unpublished manuscript in file with author.

Trebilcock, note 7, pp. 78-81.

Ibid., pp. 78-79.

16 H. Jessen, Trade and Development Law, in: M. W. Gehring and M-C. C. Segger (eds.) Sustain17 able Development in World Trade Law, Hague 2005, p. 87.

Sen, note 13, pp. 3-53. 
him the five kinds of freedom instrumental in the development process are: political freedom, economic facilities, social opportunities, transparency guarantees and protective security. ${ }^{18}$ Distinguishing between (economic) growth-mediated development and (social) support-led development, he goes on to argue that the quality of life in a low income country could be significantly improved through social services programs. ${ }^{19}$

The third concept underpinning development dogma is the empowerment approach to development. The empowerment approach takes 'collective' as its point of reference. ${ }^{20}$ The overwhelming emphasis of this approach is the creation of enabling environments for collectives to realize their maximum potential under full freedom. ${ }^{21}$ This collective rightsbased approach to development is asserted as the human right to development by the United Nations. ${ }^{22}$ Even though development could not become an enforceable right, it was successfully linked to the Anglo-American version of capitalism. ${ }^{23}$ Human right to development was linked to free market capitalism. Serving this neo-liberal capitalist logic the World Bank (WB) moved away from its large scale institute and infrastructure building loans towards 'structural adjustment' policies mandating dismantling of public enterprises and promotion of market institutions. ${ }^{24}$ The International Monetary Fund (IMF) followed suit. $^{25}$ The development agenda was looked at only through the prism of the Washington Consensus. ${ }^{26}$ The neo-liberal consensus represented a shift in development strategy from a state-centered approach to a market-oriented concept. ${ }^{27}$ For the last two decades the 'fundamentalist neo-liberal hegemony' is guiding the development discourse. ${ }^{28}$ However, the neoliberal consensus is increasingly coming under pressure from what is termed as the 'postWashington Consensus'. ${ }^{29}$ Since the post-Washington Consensus is not really a 'consensus' and is yet to be a well formed development agenda I am not discussing the different

18

19

20

21

22

23

24

25

26

27

28

29

Ibid., pp. 10, 38-40.

Ibid., pp. 43-49.

Trebilcock, note 7, pp. 81-82.

Ibid.

Ibid., p. 82; also see United Nations Declaration on the Right to Development 1986, available at http://www.un.org/documents/ga/res/41/a41r128.htm, (accessed 5 May, 2010); also see Millenium Development Goals: A Gateway to the UN System's Work on MDGs, available at http://www.un.org/millenniumgoals/, (accessed 5 May, 2010); also see generally UN, Millennium Development Goals Report (New York: UN, 2008).

Payne, note 2, pp. 76-79.

Ibid.

Ibid., p. 77.

Ibid., pp. 78-79.

Payne, note 23.

Ibid., p. 79.

Ibid., pp. 79-102. 
aspects of the same at this stage. However, I will be referring to the post-Washington Consensus at a later stage of the essay.

Though these approaches are not mutually exclusive, their implementation would entail variations in emphasis on the mechanisms to ensure development. The international institutions' (significantly the WB) present focus is on the empowerment approach to development. The WB's empowerment approach propagates the establishment of enabling institutions and mechanisms in which rights could be realized, or development could be secured. ${ }^{30}$ The Bank uses its 'rule of law' policy to institute conditions that the Bank perceives to be facilitative of development. The Bank propagated 'rule of law' envisages the ideal conditions for market driven growth and development, as I will chart below.

\section{Rule of Law in Development Discourse}

Former President Bush Jr., in a New York Times article on the first anniversary of 9/11 wrote: 'We seek a just peace where repression, resentment and poverty are replaced with the hope of democracy, development, free markets and free trade ... [f]ree trade and free markets have proved their ability to lift whole societies out of poverty .... ${ }^{, 31}$ Free market and free trade linked development was thus successfully reinforced through propaganda, diplomacy, proselytization and force. ${ }^{32}$ Neo-liberalism articulates privatization, free movement of capital and goods, re-regulation in favour of capital and restructuring of the State to facilitate these policies. ${ }^{33}$ Neo-liberal policy's facilitation of capital's cause is presented as a development initiative fostering growth, improving living standards and eradicating

For a discussion on the World Bank's shifting development paradigm and its failures, see Richard C. Blake, New Developments: The World Bank's Draft Comprehensive Development Framework and the Micro-Paradigm of Law and Development, Yale H.R. and Dev. L.J. 3 (2000), pp. 161-62. The author notes: 'As a result of the debt crisis in the 1980s, however, the Bank's focus once again turned to macroeconomic, structural adjustment lending. The Bank began the policy of "conditionality", requiring country recipients of structural loans to undergo financial reforms "regarding such areas as inflation, public deficits, liberalization of foreign trade and investment, exchange rates, and land and tax reforms. The terms of "conditionality" - also known as the "Washington Consensus", as the structural reforms were designed and mandated in concert with the Washington-based International Monetary Fund (IMF) - largely failed: only one in three countries subject to these conditions was able to meet them. In the process, the Bank became the subject of worldwide criticism, particularly for "paying too little heed to the "little man"" and to the human side of development, and for not coordinating its efforts with other international development actors.'

George. W. Bush, Securing Freedoms Triumph, New York Times, Sep 11, 2002, available at http://www.nytimes.com/2002/09/11/opinion/11BUSH.html?pagewanted=printandposition=top, (accessed 3 August, 2010).

David Harvey, Neo-liberalism and the restoration of class power, in: D. Harvey (ed.) Spaces of Global Capitalism: towards a Theory of Uneven Geographical Development, London 2006, pp. $12-25$.

33 Ibid., pp. 11-25; also see David Harvey, From Globalization to the New Imperialism, in: R. Appelbaum and W. I. Robinson (eds.) Critical Globalization Studies, New York 2005, p. 98; 
poverty of the masses. ${ }^{34}$ Thus, development discourse is tied to the neo-liberal agenda by the global hegemon and the international organizations they control. Developmental support is made conditional on the structural adjustment mechanisms and institutional reforms that facilitate neo-liberal agenda advocated by the international financial institutions (IMF and WB). ${ }^{35}$ The 'rule of law' and 'good governance' principles are central in this development discourse. ${ }^{36}$ While the structural adjustments and institutional reforms reflect the developmental ideology of the WB discussed in the earlier part of the essay, the 'rule of law' movement emerges as the principal means for the creation of the enabling environment for empowerment. In reality the rule of law initiative uses law and legal reform as an instrument to create a conducive environment for privatization, free market and free trade thereby promoting the neo-liberal version of development! ${ }^{37}$ The law reform agenda's central concerns are ensuring safe and predictable entrepreneurial activity, risk free foreign investment, judicial structure securing compliance with business obligations and increasing widening of private property rights by dispossession of people and communities. ${ }^{38}$ The law and legal reform agenda is also pursued to destroy and limit the social and political forces that are perceived as possible threats to the neo-liberal process. ${ }^{39}$ The development focus (international, as well as national) is, thus, increasingly moving away from poverty reduction plans, literacy concerns, life expectancy at birth, health, sanitation etc. and increasingly focusing on creating the environment for globalization of capital and privatization. ${ }^{40}$ This essentially means the sidelining of the sustainable livelihoods concept and the human capability concept in favour of the (WB's) empowerment concept of development. Law has become an instrument of efficiency rather than a mechanism of distribution ${ }^{41}$ under such development ideology.

In the following section I do a case study of Indian labour law scenario to chart the course of the 'rule of law' in development discourse. The study shows that the law and development discourse is increasingly limiting itself to a specific understanding of the rule of law' in the development process of the country. Such understanding of the rule of law in the development process is itself antithetical to, and runs counter to the 'emancipation' of

34

35

36

37

38

39

40

41

Harvey, note 32, p. 25.

Ibid., pp. 23-24; also Kerry Rittich, Who's Afraid of the Critique of Adjudication?: Tracing the Discourse of Law in Development, Cardozo L.R. 22 (2000), pp. 931-32; also Harvey 2005, note 33, p. 92.

Rittich, Ibid., p. 932.

Ibid.

See Ibid., pp. 932-33, 935-39; also Harvey 2005, note 33, pp. 98-99.

Rittich, Ibid., pp. 933, 935-39.

Ibid., p. 932.

Ibid., p. 934. 
the masses and creates an elite-interest oriented, tainted top-down image of 'rule of law' in the process.

\section{Labour Law in Development: the Indian Example}

The Constitution of India declares its constitutional philosophy in the governance of the country in its preamble: ${ }^{42}$
"We, the people of India, having solemnly resolved to constitute India into a sovereign socialist secular democratic republic and to secure to all its citizens:
Justice, social, economic and political;
Liberty of thought, expression, belief, faith and worship;
Equality of status and of opportunity;
and to promote among them all:
Fraternity assuring the dignity of the individual and the unity and integrity of the Nation; ..."

The philosophy declared in the preamble has been elabourated throughout the rest of the document. The chapters on the Fundamental Rights of the citizens and Directive Principles of State Policy constitute the heart and soul of the preambulary philosophy. I will briefly touch upon the principal guarantees enumerated in the enforceable fundamental rights and unenforceable but fundamental directive principles in the governance of the country so far it is relevant for the protection of the workers. ${ }^{43}$ The enforceable fundamental-right chapter guarantees principles of equality and non-discrimination; ${ }^{44}$ protection of life and liberty; ${ }^{45}$ freedom of expression, assembly, union formation, movement, vocation; ${ }^{46}$ right to free education; ${ }^{47}$ protection from forced labour; ${ }^{48}$ prohibition on employment of children; ${ }^{49}$

The Constitution of India, available at Ministry of Law and Justice Website, http://lawmin.nic.in/ coi/ coiason29july08.pdf, (accessed 5 September, 2010).

The Fundamental Rights guaranteed in Part III of the Constitution are enforceable rights, whereas the Directive Principles of State Policy in Part IV are unenforceable aspirations. If a citizen of (or a person in) the country is deprived of her fundamental rights (which are mostly civil and political rights, for which the State does not need to do a positive act to avail the citizen/person of the right), the deprived person can ask the Court to enforce her rights through the issuance of appropriate Writs. But on the other hand, the Directives in Part IV (which are principally economic and social rights) need some proactive action and economic expenditure on the State's part. Therefore, these rights have been made conditional upon the availability of resources at the State's disposal. Therefore, the Courts cannot enforce rights claimed under this Part of the Constitution. The Apex Court, however, has read many of the economic and social rights as part of the inviolable civil and political rights, thereby making sense of those guarantees so far as enforceability is concerned.

Articles 14, 15, 16 of the Constitution of India.

Article 21 of the Constitution of India.

Article 19 of the Constitution of India.

Article 21-A of the Constitution of India.

Article 23 of the Constitution of India.

Article 24 of the Constitution of India. 
Directives are fundamental in the governance of the country. ${ }^{50}$ States are directed to ensure (to the reasonable extent possible within economic and other limitations) the rights to work, ${ }^{51}$ adequate means of livelihood, ${ }^{52}$ equality of wages, ${ }^{53}$ fair distribution of material resources, ${ }^{54}$ adequate protection of workers (especially children), ${ }^{55}$ provision for living wage, ${ }^{56}$ decent standard of life, ${ }^{57}$ provision for education, leisure and social and cultural development, ${ }^{58}$ appropriate conditions of work, ${ }^{59}$ maternity relief, ${ }^{60}$ assistance during old age and unemployment, ${ }^{61}$ promotion of weaker section of the population, ${ }^{62}$ appropriate nutrition and health provision, ${ }^{63}$ workers participation in management, ${ }^{64}$ equal justice and legal aid. $^{65}$

Contextualization of the abovementioned constitutional guarantees in the development discourse would suggest that the overwhelming emphasis of the constitutional guarantees is on positive acts in furtherance of an egalitarian society. Many of these guarantees are addressed at the improvement of the lives of the population at an individual level by positive interferences rather than only by creating enabling environment. The constitution endeavors to achieve development for individuals and communities through provision for education, enabling a political and economic environment consistent with civil, political and economic rights, protection from degrading and inhuman labour, fair distribution, overall protection of the working people, and impartial redress of the grievances. Some part of the fundamental rights are negative in character (that is, non-interference by the State in individual's affair), but a significant part of the rest of the fundamental rights and directive principles are positive in nature (entailing state initiatives in ameliorating the conditions of the people). Where characteristics of all three development dogmas (discussed in the previ-

50 51

52

53

54

55

56

57

58

59

60

61

61

62

63

64 65

Article 37 of the Constitution of India.

Article 41 of the Constitution of India.

Article 39 of the Constitution of India.

Articles 38, 39 of the Constitution of India.

Article 39 of the Constitution of India.

Article 39 of the Constitution of India.

Article 42 of the Constitution of India.

Article 43 of the Constitution of India.

Article 41 of the Constitution of India.

Article 42 of the Constitution of India.

Article 42 of the Constitution of India.

Article 41 of the Constitution of India.

Article 46 of the Constitution of India.

Article 47 of the Constitution of India.

Article 43-A of the Constitution of India.

Articles 38, 39-A of the Constitution of India. 
ous section of the paper) can be found in the constitutional guarantees, there is a definite emphasis on the 'human capability approach' (or human resource development) to development underlying the fundamental rights and directive principles. I have pointed out at the outset that the Constitution of the country provides for an 'emancipatory trajectory' for the marginalized population in general and workers in particular. The content of the 'trajectory' expresses the capability approach to development as delineated by Sen. Sen argues: '[w]hat people can positively achieve is influenced by economic opportunities, political liberties, social powers, and the enabling conditions of good health, basic education, and the encouragement and cultivation of initiatives. ${ }^{66}$ He further asserts: '[d] evelopment requires the removal of major sources of unfreedom: poverty as well as tyranny, poor economic opportunities as well as systematic social deprivation, neglect of public facilities as well as intolerance or overactivity of repressive states. ${ }^{67}$ He argues the significance of public facilities, social protection, health care and educational needs for an actual overall development of the vast number of people throughout the globe. ${ }^{68} \mathrm{He}$ attributes only a marginal role to economic growth in actual development of the vast numbers. ${ }^{69}$

By providing for constitutional rights to life, health, education, social protection etc. the Constitution of India seeks to provide enabling infrastructure for actual human development. A careful perusal of the Fundamental Rights and the Directive Principles of State Policy with respect to work and the workers would clarify that most of the guarantees are aimed at improving human capability. Provision for means of livelihood, equality of wages, protection from forced labour, prohibition on employment of children, distribution of resources, protection of workers, provision for living wage, decent standard of life, appropriate conditions of work, health and maternity relief, appropriate nutrition, old age assistance, workers participation in management, is to be ensured by the State at the individual or the community level of the workers. The plethora of Supreme Court decisions has shown the futility of the institutional-empowerment approach in this regard. ${ }^{70}$ Despite establishing

66

67

68

69 70

Sen, note 13, p. 5.

Ibid., p. 3.

Ibid., pp. 3-34.

Ibid., p. 3-34.

See Bandhua Mukti Morcha v. Union of India (1984) 3 Supreme Court Cases (hereinafter 'SCC') 161; Babulal Parate v. State of Maharashtra, All India Reporter (hereinafter 'AIR') 1961 Supreme Court (hereinafter 'SC') 884; Consumer Education and Research Centre v. Union of India, (1995) 3 SCC 42; Paschim Banga Khet Mazdoor Samity v. State of W.B., (1996) 4 SCC 37; Olga Tellis v. Bombay Municipal Corporation, (1985) 3 SCC 545; State of H.P. v. Umed Ram, (1986) 2 SCC 68; Upendra Baxi v. State of U.P., (1983) 2 SCC 308; Rudul Sah v. State of Bihar, (1983) 4 SCC 141; People's Union for Democratic Rights v. Union of India, (1982) 3 SCC 235; Standard Vacuum Refining Co. of India v. Workmen, AIR 1961 SC 895.

These are some of the representative cases where the Supreme Court extended the institutional protection to be applicable to typical individual requirements. The nature and scope of the institutional protection have been defined by the Supreme Court in its interpretation of Fundamental Rights in Part III, and Directive Principles in Part IV of the Constitution of India. The 
appropriate institutions and structures to build an egalitarian society, rights of the citizens had to be realized through the intervention of the judiciary at an individual level, ${ }^{71}$ in which process the judiciary earned for itself the distinction of being one of the most activist judiciary of the world. ${ }^{72}$ Although constitutional guarantees viz., non-discrimination, protection of life and liberty, right to association require appropriate institutional mechanisms, actual experience has time and again showed that only institutional structures by themselves cannot ensure these human rights to the citizens; there have to be proactive initiatives taken by the executive at the micro-level under guidance of the judiciary. ${ }^{73}$ Thus, the nature of development envisaged by the Constitution of India is primarily the capability approach, which is constructively supplemented by the sustainable development approach and the empowerment approach.

I now trace the development of the constitutional development-paradigm to show how the Grundnorm has become subservient to neo-liberal development propaganda, thereby perpetuating the inequalities and adversaries of the societies. I take the example of labour laws in testing my hypothesis. Labour law in India is to a great extent judge developed law. Therefore, while looking at the neo-liberal influence on labour law I analyse the judicial decisions to point out how these decisions have altered the course of labour law to suit the development rhetoric.

More than $90 \%$ of the country's workforce is engaged in informal employments. ${ }^{74}$ These workers are mostly outside the purview of labour legislations in the country. It is because of the typical characteristics of employment in informal activities that laws are either not applicable to these workers or are extremely difficult to administer. Informal employment is characterized by: diverse and scattered places of employment; prevalence of

Court specifically extended the scope of the Articles 14, 19 and 21 to the needs of the people. In absence of such active interference by the Court the constitutionally guaranteed 'institutionalempowerment' mechanism would have largely been a policy objective incapable of practical realization. 71

71

'Legal Empowerment and the informal economy', SEWA, at p. 2, available at http://www.snapundp.org/lepknowledgebank/Public\%20Document\%20Library/SEWA\%20-\%20Legal\%20

Empowerment\%20and\%20the\%20informal\%20economy.pdf, (accessed 5 September, 2010). 
home-based work; unorganized, migrant and illiterate workers; ${ }^{75}$ no definite workplaces. ${ }^{76}$ These characteristics coupled with inadequate enforcement machinery ${ }^{77}$ results in the exclusion of most of these $93 \%$ of the workers from legislative protections.

Against this backdrop the Supreme Court of India, working under a socialist Constitution, had the opportunity to interpret the definition of "industry" under the Industrial Disputes Act (IDA) $1947^{78}$ in the year 1978. The Court's decision would, for the course of next four decades, shape the nature of industrial relations - both for organized and the unorganized workers. In Bangalore Water Supply \& Sewerage Board, v. A. Rajappa and Others ${ }^{79}$ the Supreme Court was called upon to clear the air by determining the true import of the term 'industry' as used in the 1947 statute. ${ }^{80}$ Working under a socialist constitution and under circumstances prevailing in the country where the significant majority of the workers were (and still are) excluded from legislative protection it would seem only natural for the Court to interpret the term in such a manner so that the majority of the work-relations (and thereby, majority of the workers) could be brought under its definition, and thereby brought under the protective umbrella of the statute. The majority of the court speaking through Justice Krishna Iyer deconstructed the definition. To them an industry would be a: ${ }^{81}$

(i) systematic activity, (ii) organized by co-operation between employer and employee ... (iii) for the production and/or distribution of goods and services calculated to satisfy human wants and wishes ...'

Though the definition would still go on to exclude a whole range of self-employed workers, it nonetheless addresses the cause of the significant number of workers who are traditionally outside the labour law purview by making the law applicable to even small establishments where employer-employee relation exists. Thus, a liberal beneficial reading of the definition would help the workers receive legislative protection. Justice Iyer, while deciding the case passionately asserted one of the foundational aspects of Indian labour jurisprudence. He observed:

See Manohar Lal, Labour Administration and the Informal Economy in India, available at http://www.ilo.org/wcmsp5/groups/public/---dgreports/---dcomm/---webdev/documents/ publication/wcms_082380.pdf, (accessed 2 September, 2010). Legal Empowerment.

Lal, note 75 .

An Act to promote amicable industrial relations and settlement of disputes principally between workers and employers. 1978 (002) SCC 213.

The IDA in section 2(j) defines: “industry" means any business, trade, undertaking, manufacture or calling of employers and includes any calling service, employment, handicraft, or industrial occupation or avocation of workmen'.

1978 (002) SCC 213, paragraph 140. 
'[P]ersonality of the whole statute has a welfare basis. The mechanism of the Act is geared to conferment of benefits to workmen and resolution of conflicts. Its goal is amelioration of the conditions of the workers, not from a neutral position but from a concern for the welfare of the weaker lot. $^{, 82}$ (emphasis added). 'A worker oriented statute must receive a construction where the keynote thought must be the worker and the community as the constitution has shown concern for them in Articles 38, 39 and 43, ${ }^{83}$ (emphasis added)

The definition so clarified by the apex court in 1978 was being interpreted differently by different courts, sometimes in conflict with each other. ${ }^{84}$ This necessitated the Court to revisit the definition in 2005 , albeit with a different orientation this time - a neoliberal orientation. Though the constitution of India is still socialist and the fundamental rights and directives to the states have not been amended, the country has been proselytized with the idea of neo-liberal development doctrine by this time. The rule of law, good governance and restructuring propaganda did penetrate the judiciary and the lawmakers. ${ }^{85}$ The Supreme Court in 2005 found with fervent zeal that its 1978 clarification of the definition of "industry" is not authoritative, and the IDA is not labour welfare legislation. ${ }^{86}$ The Court speaking through Justice Dharmadhikari, in a significant departure from its earlier approach (especially during the 1970 s and 1980s) observes: ${ }^{87}$

' $\ldots$ the statute under consideration cannot be looked at only as a worker-oriented statute. ${ }^{88}$ 'A worker oriented approach in construing the definition of industry, unmindful of the interest of the employer or the owner of the industry and the public who are ultimate beneficiaries, would be a one sided approach and not in accordance with the provisions of the Act.'

The Court further observes: ${ }^{89}$

"An over expansive interpretation of the definition of "industry" might be a deterrent to private enterprise in India where public employment opportunities are scarce. The people should, therefore, be encouraged towards self-employment. To embrace within the definition of "industry" even liberal professions like lawyers, architects, doctors, chartered accountants and the like, which are occupations based on talent, skill and intellectual attainments, is experienced as a hurdle by professionals in their self pursuits. In carrying on their professions, if necessarily, some employment is generated, that should not expose them to the rigors of the Act. No doubt even liberal professions are required to be regulated and reasonable restrictions in favour of those employed for them can, by law, be imposed, but that should be subject of a separate suitable legislation.'

1978 (002) SCC 213, Paragraph 18.

1978 (002) SCC 213, Paragraph 12.

See State of U.P. v. Jai Bir Singh, (2005) 5 SCC 1.

See generally S.B. Sinha, Constitutional Challenges in the $21^{\text {st }}$ Century, National Law School of India Review 21: 1 (2009), p. 117; also see S. B. Sinha, Emerging Industrial Relations, Supreme Court Cases (Journal) 6 (2004), p. 1.

State of U.P. case.

State of U.P. case, paragraph 42.

State of U.P. case, paragraph 37.

State of U.P. case, paragraph 40, 41. 
Thus, having argued that an expansive definition of 'industry' leads to unemployment the Court linked up workers' employment opportunities with a narrower definition of 'industry'. The Court argued that overemphasis on the rights of the workers leads to undue financial hardship on the part of the employer. Such hardship results in ousting the employer from the market, which adversely affects the workers. ${ }^{90}$ Thus, the underlying justification for challenging the existing expansive definition by the Court was based on development rhetoric in terms of creation of employment. The Court implied that such generation of employment could be possible only when private entrepreneurship is given unrestricted freedom (free from any obligation) to operate in a market economy. This implication of the Court strikingly resonates with the neo-liberal development logic of the 'Washington consensus' and structural adjustment policies forced by the international financial institutions. Having thus taking up the neo-liberal crusader role, the Court refers the matter to a higher Bench for a revision of the definition of 'industry'. The higher Bench is, however, yet to be constituted, thereby leaving the 1978 decision unaltered. The Court itself could not overrule the 1978 decision because of a lower Bench strength than the former one. It is still the 1978 decision that decides when an entrepreneurship would be an 'industry'.

In the present climate of neo-liberal 'rule of law' proselytization, the structural adjustment most relevant for capital against labour is labour flexibility. Labour flexibility is dealt with by the Contract Labour (Regulation and Abolition) Act, (CLRA) 1970 in India. ${ }^{91}$ The statute permits employment of labour on a contract basis. The statute also compels abolition of the contract labour system from any industry, and thereby promotes the use of regular employees under certain circumstances. ${ }^{92}$ During the 80 s' and 90 s' decades, the

90

91

Expressing the legislative intent in a nutshell the long title of the Act reads: 'An Act to regulate the employment of contract labour in certain establishments and to provide for its abolition in certain circumstances and for matters connected therewith'. Thus, wherever abolition of the system was not possible, the legislation requires proper regulation of the system. The principal object was to arrest the growth of contract labour and where its abolition is not possible, to regulate the conditions of employment to prevent exploitation and atrocities associated with and inherent in the system.

The CLRA Act regulates the employment of contract workers in non-regular and seasonal jobs. Regulation of employment of contract workers ensures appropriate conditions at work and other welfare measures. But, however, the law prohibits employment of contract workers for works that are regular and perennial in nature, and has to be performed on a day to day basis. The law mandates employment of permanent workers for regular and perennial jobs. The 'appropriate government' (the Union Government or the Provincial Government) is to declare abolition of contract labour from an industry if it is found that contract workers are being employed to perform regular jobs. Upon such declaration by the government contract labour system stands terminated from regular jobs in an industry, and the employer is under obligation to appoint regular employees to fill up the vacancies caused by the abolition of contract labour system. The CLRA Act is silent on the prospect of regularization of employment of the contract workers who were employed in the industry before abolition of the system. It is with respect to this silence that the Supreme Court is called upon to decide whether contract workers can claim right to regularization upon abolition of 
Supreme Court generally promoted regularization of the services of the erstwhile contract labourers upon abolition of the contract labour system from an industry, ${ }^{93}$ except for the aberration of a two judge Bench in Deena Nath and others v. National Fertiliser Ltd. and others $^{94}$ case. But, after Deena Nath decision (refusing to regularize the services of the contract workers upon abolition of contract work from the undertaking) a three judge Bench quickly restated the law in Air India Statutory Corporation v. United Labour Union. ${ }^{95}$ The Supreme Court observed in the latter case that abolition of the contract labour system ensures right of workers to their regularization as employees in the establishment in which they were hitherto working as contract labour through the contractor. The contractor stands removed and a direct employer-employee relationship is established. But a setback to the above position came with a five judge Bench judgment of the Supreme Court in the 2001 case of Steel Authority of India Limited v. National Union Waterfront Workers and others. ${ }^{96}$ This decision overruled the Air India case and restored the position laid down in Dena Nath case. Thus, as it stands today, there is no right of the contract workers to get regularized if their services are terminated, and the establishment is required to make regular appointments.

While regularization of contract workers was jeopardized by the abovementioned judgments, regularization of temporary casual workers in public sector undertaking was effectively negated by the apex court in a 2006 judgment. In 2006, in Secretary, State of Karnataka and others $v$. Umadevi and others, ${ }^{97}$ the Supreme Court held that even though the employer is entitled to get their work done by temporary and casual workers on a regular basis, they are under no obligation to regularize the service of these workers. ${ }^{98}$ Underlying the empowerment approach to development the Court's decision reasoned that regularization of temporary and casual workers, whose appointment did not follow the prescribed procedure, would prejudicially affect employment prospects of a large pool of unemployed workers. ${ }^{99}$ However, the facts of the case itself betrayed the Court's logic. The Court was dealing with cases where workers were employed for ten to twelve years as temporary workers. During this supposedly temporary period of more than ten years they

the contract labour system from an industry. See generally Standard Vacuum Refining Co. of India case.

See Lal Bevta Hotel and Bakery Mazdoor Union v. Bharat Petrolium Corporation, 1993 (1) Labour Law News (hereinafter 'LLN') 965 SC; Munna Khan v. Union of India, 1989 (Suppl.) (2) SCC 99; R.K. Panda and others v. Steel Authority of India and other, 1994 (2) LLN SC 378; N.F. Railway Porters v. Union of India, 1995 (71) FLR 75 (SC).

95

96

97

98

99

AIR 1992 SC 457.

1997 (1) LLN 75 (SC).

2001 (7) SCC 1.

2006(4) SCC 1.

See generally 2006(4) SCC 1.

2006 (4) SCC 1, paragraph 12, 36, 41, 42. 
did not receive welfare and benefits that the permanent workers were entitled to. ${ }^{100}$ Therefore, for all effective purposes the employer was getting their regular work done by employing (same set of) temporary workers who were not treated at par with permanent workers. While on one hand this is a cost saving mechanism enhancing the establishment's competitiveness, on the other, such an arrangement negates employment of the large pool of unemployed workers whose cause the Court purportedly crusades for. In the instant case even though the judges ordered regularization of employees working for more than ten years in an establishment, they prospectively negated any such regularization (even if the workers are temporarily employed in an establishment) with a direction to the employer to be judicious in their employment of temporary and casual workers. ${ }^{101}$ The Court, however, did not see any illegality in the employment of temporary or casual workers. ${ }^{102}$ The Court justified such arrangement by observing that ' $[t]$ he courts must be careful in ensuring that they do not interfere unduly with the economic arrangement of the affairs of the State or its instrumentalities ...., 103

While deciding the case, interestingly the learned judges of the Supreme Court opined that their predecessors (in the Court) misunderstood the connotation "socialist" in the preamble of the Constitution, and got swayed by that misunderstood idea in charting the course of labour jurisprudence. ${ }^{104}$ The success of neo-liberal proselytization of the Supreme Court over the socialist ideal is further apparent when a judge of the Court, writing in a law review, observed: ${ }^{105}$

' $[\mathrm{L}]$ iberalisation is essentially a laissez faire policy, which seeks to reduce the government interference to the minimum. Its primary aim is privatization and its ultimate aim is a capitalist economy. A question arises as to how far socialism, which our Constitution strives for, has suffered a setback.'

2006 (4) SCC 1. Justice P K Balasubramanyan delivering the judgment on behalf of the Court observes: 'This Court [erstwhile] seems to have been swayed by the idea that India is a socialist republic and that implied the existence of certain important obligations which the State had to discharge. While it might be one thing to say that the daily rated workers, doing the identical work, had to be paid the wages that were being paid to those who are regularly appointed and are doing the same work, it would be quite a different thing to say that a socialist republic and its Executive, is bound to give permanence to all those who are employed as casual labourers or temporary hands ...' (in paragraph 16); Baxi, reacting against such destabilizing assertion somewhat sarcastically remarked that he could not find from his research that by an amendment of the constitution the term "socialist" has been removed from the constitution, see Upendra Baxi, Dual standards of justice since globalization, International Campaign for Justice in Bhopal, available at http://www.bhopal.net/courtcases/archives/2006/08/dual_standards .html, (accessed 2 September, 2010).

Sinha 2004 , note 85 , p. 2. 
This ideology finds its place in his decision where he notes that in view of the changed economic policy of the country earlier approach to industrial relations protecting only workers interest needs to be discarded. ${ }^{106}$ On the question of socialism in a liberalized economy, in 1996 the then Chief Justice of the Supreme Court, Justice A M Ahmadi in a lecture asserted that liberalization was consistent with socialism because equitable distribution first required wealth creation. ${ }^{107}$ What such neo-liberalism entails for labour law is further explained by a 'neo-liberal Judge': ${ }^{108}$

'To catch the international bus of industrial production and compete globally, a complete change in the mindset of all concerned is required. We cannot achieve our desired economic aims, unless changes are made in our labour policy. On account of globalization, there is an increase in demand to rectify the distortions in our labour laws.'

The 'distortions' in labour laws of the country the learned judge refers to are welfare measures, beneficial provisions and safeguard measures for the workers. These are 'distortions', because these are not compatible with neo-liberal ideals. In this backdrop the underlying agenda remains the overhaul of the beneficial labour guarantees in favour of a more flexible labour regime that suits global capital. ${ }^{109}$ The Supreme Court has indeed set its foot in that direction with respect to labour jurisprudence. In consecutive cases the Court has changed its earlier position to make labour amenable to capital's requirements. The constitutional guarantee of equal pay for equal work ${ }^{110}$ has been diluted by the Court and is made subject to considerations of permanence of employment, ${ }^{111}$ educational qualification, ${ }^{112}$ sanctioned post ${ }^{113}$ etc. Wrongful terminations were earlier met with reinstatement and payment of back wages; ${ }^{114}$ such terminations are now compensated by lump sum pay-

106 See Hombe Gowda Educational Trust v. State of Karnataka, (2006) 1 SCC 430 at paragraph 26.

See Prakash Karat, Supreme Court in Liberalised Times, Countercurrents.org, available at 108 http://www.countercurrents.org/hr-karat090803.htm, (accessed 2 September, 2010).

109

Sinha 2004, note 85, p. 2.

See generally Ibid.

Articles 38, 39.

111

State of Orissa v. Balaram Sahu, AIR 2003 SC 33; State of Rajasthan v. Kunji Raman, AIR 1997 SC 693; Mahendra L Jain v. Indore Development Authority, (2005) 1 SCC 639; Apangshu Mohan Lodh v. State of Tripura, AIR 2004 SC 267.

112 HP Gupta v. Union of India, (2002) 10 SCC 658; MP Rural Agriculture Extension Officers Association v. State of MP, AIR 2004 SC 2020.

113 Ghaziabad Development Authority v. Vikram Chaudhary, AIR 1995 SC 2325.

114 State Bank of India v. N. Sundara Money, (1976) I Labour Law Journal (hereinafter 'LLJ') 478 SC; L. Robert D'souza v. Executive Engineer, Southern Railways, (1982) I LLJ 330 SC; Punjab Land Development and Reclamation Corporation Ltd., Chandigarh v. Presiding Officer, Labour Court, Chandigarh, (1990) II LLJ 70 SC. 
ments, ${ }^{115}$ and reinstatement is possible only in rare cases. ${ }^{116}$ Burden of proving the fact of employment relation has been shifted from the employer ${ }^{117}$ to the worker, ${ }^{118}$ despite the mandatory burden of the employer to keep workers' records under law. ${ }^{119}$ Such shift in burden makes it easier for the employer to manipulate employment relations by avoiding documentation, especially in a country where majority of the workers are illiterate. Recently the Court upheld the disinvestment of Bharat Aluminium Company Limited (BALCO) (erstwhile a Government of India undertaking) by the Government of India, made without even giving hearing to the workers. ${ }^{120}$ The decision was again made in negation of constitutional requirement of workers' participation in management. ${ }^{121}$ The Court categorically rejected any requirement of prior notice to the workers by the management (in this case, the Government of India) before disinvestment decision, even if such decision affects workers' interest. ${ }^{122}$ Justifying the disinvestment decision of the government the Court observed that due to changes in economic climate it was necessary for the government to change its policy in 'public interest'. ${ }^{123}$ The Court further held that the disinvestment decision might have been propelled by the need to generate funds to use for development projects, welfare programs and to enhance efficiency and competitiveness, ${ }^{124}$ thus implying that it would be myopic to attend to only the workers' causes ('social security', 'stock options' etc.) who worked in BALCO. Thus, the above orientation of the highest judiciary, capable of changing laws, obliterates worker's welfare and benefits to establish rule of law suitable to neo-liberal capitalism (albeit under the 'development' garb), thereby propagating the neo-liberal development paradigm. Gradual invocation of the neo-liberal rule of law, however, directly interferes with the welfare, and therefore development in the sense of 'emancipation' of the workers. The abovementioned alarming neo-liberal sycophancy of the Court has recently been lamented by two judges of the Apex Court in utter

Rolston John v. Central Government Industrial Tribunal cum Labour Court, AIR 1994 SC 131; Employers, Management of Central P and D Institute Ltd. v. Union of India, AIR 2005 SC 633; Haryana Tourism Corporation Ltd. v. Fakir Chand, AIR 2003 SC 4465; Branch Manager, M.P. 116 State Agro Industries Development Corporation Ltd. v. S. C. Pandey (2006) 2 SCC 716.

117 K. C. P. Employees Association, Madras v. Management of K. C. P. Ltd., Madras, AIR 1978 SC 474.

Range Forest Officer v. HD Hadimani, AIR 2002 SC 1147.

119 Section 25D of the Industrial Dispputes Act 1947.

120 BALCO Employees Union v. Union of India, AIR 2002 SC 350.

121 Article 43A of the Constitution of India. Moreover, in National Textile Workers' Union v. P.R. Ramakrishnan, (1983) 1 SCC 228 case, the Court had held that workers have a right to be heard in the winding up proceedings of a company.

123 $B A L C O$ case.

124 $B A L C O$ case.

$B A L C O$ case. 
desperation. In a judgment delivered in January $2010^{125}$ a division bench of the Court anxiously points out: ${ }^{126}$

'Of late, there has been a visible shift in the courts approach in dealing with the cases involving the interpretation of social welfare legislations. The attractive mantras of globalization and liberalization are fast becoming the raison d'etre of the judicial process and an impression has been created that the constitutional courts are no longer sympathetic towards the plight of industrial and unorganized workers.'

The judges asserted that this disturbing trend is mistakenly sought to be validated in the name of globalization and liberalization of the economy. ${ }^{12}$

The neo-liberal development ideal is based on the contested (if not faulty) premise of economic development percolating down to the lower strata of the society. ${ }^{128}$ The discourse is based upon an economic growth-based understanding of the development paradigm. But, it has been established that development never happens equally on a nationwide (or international) scale. ${ }^{129}$ It is the elites of the respective societies that benefit from the economic development process. ${ }^{130}$ The voice of the poor and marginalized is not heard and their plight is ignored in the dominant development paradigm. ${ }^{131}$ Such a 'one size fits all' approach spelled the doom for the law and development discourse in its earliest incarnation during the 1960 s and 1970 s decade. ${ }^{132}$ After the 'lost decade' for development during 1980-1990, the discourse revived with new enthusiasm upon the celebrated end of socialism as a state policy at the end of the 90 s decade. ${ }^{133}$ The industrialized countries (or more accurately, the United States) left no opportunity to proselytize the newly democratic countries (and the erstwhile colonized countries) to neo-liberal ideals through the interna-

Harjinder Singh v. Punjab State Warehousing Corporation, Special Leave to Appeal (Civil) No(s). 6966/2009, available at http://courtnic.nic.in/supremecourt/temp/dc\%20696609p.txt, (accessed 21 August, 2010).

See Harjinder Singh, judgment delivered by Justice A K Ganguly.

See Joseph E. Stiglitz, Globalozation and its Discontents, New York 2003, pp. ix-xvi, 3-10, 20, 21, 214-222, 248-250.

129 See generally Sandra Halperin, Re-envisioning global development: conceptual and methodological issues, Globalizations 4: 4 (2007), pp. 543-58; Also see John Samuel, India: Growth without development: rhetoric and deprivation, available at http://unpan1.un.org/intradoc/groups/public/ documents/apcity/unpan007048.pdf, (accessed 1 September, 2010).

Halperin, Ibid., pp. 543-58; also Stiglitz, Note 128; also see Samuel, Ibid.,

131 Blake, note 30, pp. 173-74, 178-81, 184, 187-88.

132 See generally David M. Trubek and Mark Galanter, Scholars in Self-Estrangement: Some Reflections on the Crisis in Law and Development Studies in the United States, Wis. L. Rev. (1974), p. 1062 .

133

Ruth E. Gordon and Jon H. Sylvester, Deconstructing Development, Wis. Int'1 L.J. 22 (2004) p. 40-48. 
tional institutions headquartered in the United States. ${ }^{134}$ If the purpose of the first phase of the development rhetoric was the improvement of the living standards of the vast majority of the population in the newly independent states after the World War II, the purpose of the latest phase of the development process is the creation of inroads for international capital to every nook and cranny of the world. ${ }^{135}$ Actual improvement of living standards has become subservient to structural adjustment goals.

The law and development discourse needs to come out of the terms set by the international financial institutions and take a more holistic and perhaps more pluralistic outlook towards development, ${ }^{136}$ and reconsider how law shapes and influences the varieties of development(s). The discourse needs to reconstitute itself around law and development(s) studying the role of law at different levels and the varieties of development, all of which is capable of emancipating people's lives in diverse and nuanced ways. In such a form the law that shapes development need not necessarily be international law or domestic law modeled on 'international model laws'; domestic laws per se can be agents of development, or as I have shown, can curb development! Therefore, if repositioning the 'law and development' discourse is not done the efficacy and authenticity of the law and development discourse could be challenged, and charges of bias leveled against the discourse. One of the prior requirements for such paradigm shift would be to revisit and reconstruct the development discourse. The diverse range of interconnected development ideas denoted as the "postWashington Consensus' opposes the 'one size fits all' approach of the neo-liberal development discourse, and suggests a more nuanced state-centric development construct. ${ }^{137}$ Varieties of state-centered and support-led approaches proposed by Stiglitz, Sen, Fine etc. are hailed as the 'post-Washington Consensus'. ${ }^{138}$ The so called consensus proposes nonhegemonic development agendas characterized by proposals of self determination, looking beyond Gross Domestic Product, greater appreciation of country-specific historical evolu-

Gordon and Sylvester, Note 133. The difference in purpose in these two phases of development rhetoric could be explained by the prevailing international scenarios. After the second World War, when the world was divided in two political philosophies, the capitalist part of the world was overactive to shape the newly independent countries on liberal capitalist ideals, so that these new nations does not end up becoming socialist in orientation. Therefore, the focus of the development agenda was people and their well being. But, however, after the end of USSR and the cold war during late 1990s, the threat of socialism seemed to have withered away, as well as its appeal! Therefore 'well being of the masses' somehow became secondary to the predatory capitalism because the chances of reverting to socialism now seemed impossible. Hence, the world started being proselytized with the capitalist logic of economic benefits percolating down the society. Development started being expressed in terms of gross domestic product, gross national product, per capita income etc., and not malnutrition, infant and maternal mortality, health, education etc.

Maxwell O. Chibundu, Law in Development: On Tapping, Gourding and Serving Palm-Wine, Case W. Res. J. Int'l L. 29 (1997), pp. 222-224.

Ibid. 
tion, strategic integration of domestic and international economy. ${ }^{139}$ Thus, instead of following the neo-liberal bandwagon it might just be advisable for the domestic legal regimes to look for other alternative approaches to development from amongst the ones that suits a country's typical development requirements. As Sen contends: '[t]he support-led process is a recipe for rapid achievement of higher quality of life, and this has great policy importance, but there remains an excellent case for moving on from there to broader achievements that include economic growth as well as the raising of the standard features of quality of life.' Thus, economic growth-led development could successfully be build over the human or capability development achieved through the support-led process. But, unfortunately the Indian Supreme Court is found to have been using 'rule of law' as an obstacle (rather than facilitator) in the gradual development of the workers in the labour law context.

\section{E. Conclusion}

As I have discussed in the Indian context, law in the development discourse has now come to mean only laws that facilitate the neo-liberal market economy. All other laws that can be instrumental (and have been instrumental) in actual development of the vast majority of the population have become subservient to the neo-liberal approach. Thus, one ideal of development (neo-liberal ideal of empowerment) forecloses the other more direct developmental ideals (support-led capability development) because of the formulation of the development discourse. Present development discourse helps only the elites in a country - it is not a phenomenon that benefits the masses throughout the country. ${ }^{140}$ Indian development under neo-liberal influence has been a story of elitist growth and marginalization of the poor. ${ }^{141}$ The present set of laws ${ }^{142}$ further marginalizes the already marginal and less privileged people within the country. Laws that could actually make a difference, eg., welfare and 'emancipatory' laws are increasingly either scrapped or made ineffective by the judiciary thus, law and development discourse becomes an elitist concept facilitative only of capital accumulation, and hence its credibility is increasingly lost. The judiciary is however, not alone in this neo-liberal development quest. ${ }^{143}$ The legislature is equally proselytized in the

139

140

Ibid., pp. 96-98.

See generally Halperin, note 129; also Samuel, note 129.

141 See Samuel, Ibid.

142 The present set of 'good law' (in the law and development context) are the laws that facilitate the neo-liberal market economy; 'bad law' are the ones that interferes with the market economy, which in the present context would be the non-flexibility of labour regime. See Rittich, Note 35, pp. 931-39; also Harvey 2005, Note 33, pp. 98-99.

143 See The Special Economic Zones Act, 2005, available at http://www.sezindia.nic.in/ writereaddata/pdf/SEZ\%20Act,\%202005.pdf, and the five state enacted laws and rules on special economic zones, available at http://www.sezindia.nic.in/state-policies-ssa.asp?id=2, (accessed 6 August 2010). 
same direction. ${ }^{144}$ It would be worthwhile to analyse the role of SEZ laws on (fundamental and) labour rights. ${ }^{145}$ Thus, if law is to be meaningfully studied in developmental discourse, the myriad functions of law in actual development processes of the masses needs to be empirically studied and theorized - otherwise the law and development discourse will suffer a long predicted demise as far removed from reality.

It is heartening to note that recently ${ }^{146}$ the Supreme Court of India sought to remind us the dangers that neo-liberal sweep of 'rule of law' holds over the country, and sought to correct the wrong done by the court in the meantime. The Court observes: ' $\ldots$ any attempt to dilute the constitutional imperatives in order to promote the so called trends of "globalization", may result in precarious consequences. '147 The Apex Court of the country resolves: 'At this critical juncture the judges' duty ... is to uphold the constitutional focus on social justice without being in any way mislead by the glitz and glare of globalization. ${ }^{148}$ Only time will tell whether this is the beginning of a welcome change or just an instantaneous spark of two insightful judges.

Thus, the hectic journey of the 'rule of law' in development discourse has shown that the movement can only be successful if we leave behind the baggage of predominant capitalist ideology and relate development to real differences in the lives (i.e., more pluralistic development paradigms) of the weakest of the lot and use law to address the identified pluralistic goals. Hence, rule of law in development context should not only be structural it must have the substantive characteristics to improve lives of the large majority.

See Anantha N. Sriram, New Mechanisms of Imperialism in India: The Special Economic Zones, Socialism and Democracy 22: 1 (2008) pp. 35-60.

See Jayati Ghosh, The bottom line, New Internationalist, September 2007, available at http://www.newint.org/features/special/2007/09/01/special_feature/, (accessed 6 September 2010); also see Jaivir Singh, Labour Law and Special Economic Zones in India - Reforming labour laws is better than cleverly nudging its practice, Pragati The Indian National Interest Review, available at http://pragati.nationalinterest.in/2009/08/labour-law-and-special-economiczones-in-india/, (accessed 6 December 2010).

Harjinder Singh case.

147 See Harjinder Singh, judgment delivered by Justice A K Ganguly. 